\title{
CLINICAL EVALUATION OF THE HEALING PROCESS OF ORAL SOFT TISSUE SURGICAL WOUNDS STIMULATED BY LOW-LEVEL LASER THERAPY
}

\author{
Hristina Lalabonova ${ }^{1}$, Elena M. Ilieva ${ }^{2}$ \\ 1) Department of Maxillofacial Surgery, Faculty of Dental Medicine, Medical \\ University -Plovdiv, Bulgaria. \\ 2) Department of Physical and Rehabilitation Medicine, Medical Faculty, Medical \\ University - Plovdiv, Bulgaria.
}

\begin{abstract}
During the past decades laser therapy gained much popularity in clinical practice. Low-level lasers offer alternative solutions to numerous problems in oral surgery.

Purpose: The purpose of the present study is to evaluate clinically the healing process of soft tissue surgical wounds in the oral cavity stimulated by low-level laser therapy (LLLT).

Materials and methods: One hundred and twenty surgical wounds were assigned to three groups: Group I included 40 patients who underwent red spectrum LLLT with wavelength $(\lambda)$ of $658 \mathrm{~nm}$; Group II -40 patients treated with infra-red LLLT with $\lambda$ of $904 \mathrm{~nm}$; Group III (control group) - 40 patients without LLLT. In Group I and II the LLLT procedures were applied 1 day before, in the day of and 1 day after the operation. Distant emission with a focused beam through an angled conical probe $3 \mathrm{~mm}$ in diameter $(3 \mathrm{~mm})$ was used. The irradiated area is $0,5 \mathrm{~cm}^{2}$. The area of impact is the surgical wound zone and the neighboring $0,5-1,0 \mathrm{~cm}$ of the adjacent oral mucosa.

Results and discussion: The evaluation of the healing process included the following criteria: pain, edema, hyperemia, time for wound closure, postoperative complications.

Conclusions: LLLT applied with the offered treatment modality accelerates the healing process of soft tissue surgical wounds in the oral cavity, reduces treatment time and restores patients' comfort
\end{abstract}

Key words: oral mucosa, LLLT, treatment, surgical wounds, oral surgery.

\section{INTRODUCTION}

In the past decades laser therapy gained much popularity in clinical practice.(10) Due to its high efficacy it is currently used in numerous medical fields. $(1,4,7,8)$
The wide range of biologic effects of laser therapy makes it applicable in oral surgery. Low-level lasers offer alternative solutions to numerous problems met in the everyday practice. $(2,3,5,6,9)$

The goal of the present work was to assess clinically the healing of soft tissue operative wounds in the oral cavity stimulated by low power laser emission.

\section{MATERIALS AND METHODS}

The objectives of the study were 120 surgical wounds formed as part of the operative treatment of periapical lesions of the jaws and preprosthetic surgical corrections of the alveolar process preceding the functional reconstruction of the dentition. The wounds were distributed into 3 groups.:

Group I (test-group) included 40 patients in whom the healing process was stimulated with red spectrum LLLT applied by a developed by the authors method. The LLT was conducted with diode laser "SIX LASER TS" with wavelength $(\lambda)$ of $658 \mathrm{~nm}$.

Group II (test-group) comprised of 40 patients who underwent stimulation of the healing process with infra-red LLLT. The latter was executed by a method developed by the authors using the "Prometeus" laser apparatus with $\lambda$ $904 \mathrm{~nm}$. \section{LLLT.}

Group III (control) consisted of 40 patients with no

In Group I и II the LLLT procedures were applied 1 day before, in the day of and 1 day after the operation. We used distant emission with a focused beam through an angulated conical probe $3 \mathrm{~mm}$ in diameter $(3 \mathrm{~mm})$. The irradiated area is $0,5 \mathrm{~cm}^{2}$. The area of impact is the surgical wound zone and the neighboring $0,5-1,0 \mathrm{~cm}$ of the adjacent oral mucosa. The parameters of laser emissions are as follows: 
For $(\lambda) 658$ nm LLLT:

To obtain analgesic effect only:

$\begin{array}{ll}\text { - power } & \mathrm{P}-30 \mathrm{~mW} \\ \text { - frequency } & \mathrm{f}_{1}-5,8 \mathrm{~Hz} \\ & \mathrm{f}_{2}-5,8 \mathrm{~Hz} \\ \text { - time } & \mathrm{T}-1 \mathrm{~min} 22 \mathrm{sec} \\ \text { - dose } & \mathrm{E}-2 \mathrm{~J} / \mathrm{cm}^{2}\end{array}$

To obtain analgesic/antiflogistic effect:

$\begin{array}{ll}\text { - power } & \mathrm{P}-30 \mathrm{~mW} \\ \text { - frequency } & \mathrm{f}_{1}-5,8 \mathrm{~Hz} \\ & \mathrm{f}_{2}-\mathrm{CW} \\ \text { - time } & \mathrm{T}-1 \mathrm{~min} 14 \mathrm{sec} \\ \text { - dose } & \mathrm{E}-2 \mathrm{~J} / \mathrm{cm}^{2}\end{array}$

For $(\lambda) 904$ nm LLLT:

To obtain analgesic effect only:

$\begin{array}{ll}\text { - power } & \mathrm{P}-20 \mathrm{~W} \\ \text { - frequency } & \mathrm{f}-1000 \mathrm{~Hz} \\ \text { - time } & \mathrm{T}-1 \mathrm{~min} \\ \text { - dose } & \mathrm{E}-2 \mathrm{~J} / \mathrm{cm}^{2}\end{array}$

To obtain regenerative effect

$\begin{array}{ll}\text { - power } & \mathrm{P}-20 \mathrm{~W} \\ \text { - frequency } & \mathrm{f}-300 \mathrm{~Hz} \\ \text { - time } & \mathrm{T}-3 \mathrm{~min} \\ \text { - dose } & \mathrm{E}-1,5 \mathrm{~J} / \mathrm{cm}^{2}\end{array}$

The assessment of the healing process included the following criteria: pain, edema, hyperemia, time for wound closure, postoperative complications. The fore-mentioned indices were evaluated on the 1-st, 3-rd and the 5-th day after the operation.

The statistical analysis of the obtained data was made with SPSS v. 17 и MS Office Excel 2003 package.

\section{RESULTS AND DISCUSSION}

The distribution of the patients by gender is $58,3 \%$ men, $41,7 \%$ women. The mean age is $45,83 \pm 1,35$ years.

The obtained data from the followed-up parameters pain, edema, hyperemia, time for wound closure, postoperative complications are as follows:

\section{Pain}

Day 1: $32,5 \%$ of the patients in group I $32,5 \%$ suffered pain, the patients in group II are painless, and $75 \%$ of the patients in group III also suffered pain.
Day 3: all patients in groups I and II are painless, $10 \%$ of the patients from the group III had pain.

Day 5: the patients from all groups are painless.

\section{Hyperemia}

Day 1: the patients in group I who had wound hyperemia were $35 \%$, in group II $-30 \%$, and in group III $-50 \%$.

Day 3: the patients with erythematous wounds in group II are $7,5 \%$, in group III $-20 \%$, and all patients in group I had no wound hyperemia.

Day 5: the patients in all groups had no wound hyperemia.

\section{Edema}

Day 1: $100 \%$ of the patients in group I and $47,5 \%$ of the patients in group II had insignificant edema; in group III $12,5 \%$ of the patients exhibited massive and $75,5 \%$ insignificant edema.

Day 3: all patients in group I and II had no edema, 7 , and $5 \%$ of the patients in group III had insignificant edema.

Day 5: the patients in all groups had no edema.

\section{Postoperative complications}

In groups I and II no postoperative complications were noted, while in group III the rate of postoperative complications was $5 \%$.

\section{Wound closure}

In group I $(\lambda \mathbf{6 5 8} \mathbf{n m})$ the mean time for closure of the wound was $5,88 \pm 0,05$ days, in group II ( $904 \mathbf{~ n m})-$ $5,43 \pm 0,10$ days, and in the control group $-7,03 \pm 0,0$ days.

From the results obtained it can be summarized that the healing process of soft tissue surgical wounds is stimulated by LLLT. Surgery is a stress-factor to the individual. General and local signs after the operative trauma have different character. Until healing is accomplished the changes in soft tissues pass through several stages and going from stage to stage is smooth and gradual. The biological stimulating effect of lasers applied in low power of $\mathrm{mW} / \mathrm{smI}$ is manifested with acceleration of the process of rehabilitation and regeneration, antiflogistic and analgesic. $(4,5,8,10)$. The process of wound healing passes from alteration through proliferation to reach the phase of epitelization. In stimulating the healing processes certain role play the instigation and growth of the epithelium and the growth and formation of new blood vessels. 


\section{CONCLUSION}

Low level laser therapy applied by the offered method of acceleration of the healing process of the soft tissue surgical wounds in the oral cavity is an effective, easily applicable and comfortable therapeutical option. It helps in reduction of the healing time and raises the quality of the results. The patients are offered a method of stimulation of the healing process and pain control without the use of drugs contributing to the rehabilitation and comfort in the postoperative period.

\section{REFERENCES:}

1. Broughton $\mathrm{H}$, Jefferey E, Janis JE, Attinger CE. Wound healing: An overview. Plast Reconstr Surg 2006 Jun;117(7 Suppl):1e-S-32eS. [PubMed]

2. Damyanov D. Surgery-Basis of the surgery, "Znanie", Sofia. 2007, vol.I, 428p. (in Bulgarian)

3. Deppe H, Warmuth S, Heinrich A, Korner T. Laser-assisted threedimensional surface modifications of titanium implants: preliminary data. Lasers Med Sci. 2005 Apr;19(4):22933. Epub 2005 Feb 22. [PubMed] [CrossRef]

4. Jakse N, Payer M, Tangl S, Berghold A, Kirmeier R, Lorenzoni M. Influence of low-level laser treatment on bone regeneration and osseointegration of dental implants following sinus augmentation. An experimental study on sheep. Clin Oral Implants Res. 2007 Aug;18(4):517-24. Epub 2007 Apr 19. [PubMed] [CrossRef]

5. Kim YD, Kim SS, Hwang DS, Kim SG, Kwon YH, Shin SH, et al. Effect of low-level laser treatment after installation of dental titanium implantimmunohistochemical study of RANKL, RANK, OPG: an experimental study in rats. Lasers Surg Med. 2007 Jun;39(5):441-50. [PubMed] [CrossRef]

6. Kotlow L. Lasers and soft tissue treatments for the pediatric dental patient. Alfa Omegan. 2008 Sep;101(3), 140-51. [PubMed]

7. Lopes CB, Pinheiro AL, Sathaiah S, Da Silva NS, Salgado MA. Infrared laser photobiomodulation (lambda 830 $\mathrm{nm}$ ) on bone tissue around dental implants: a Raman spectroscopy and scanning electronic microscopy study in rabbits. Photomed Laser Surg. 2007 Apr;25(2):96-101. [PubMed] [CrossRef]

8. Mosvin CV, Buylin BA. Foundations of laser therapy. Publishing house „Triada” Moskow, 2006, 256c. [in Russian]

9. Pinheiro AL, Cavalcanti ET, Pinheiro TI, Alves MJ, Manzi CT. Low-level laser therapy in the menagment of disorders of maxillofacial region. J Clin Laser Med Surg. 1997;15(4);181-3. [PubMed]

10. Ryazkova M, Kirova I. Physical therapy-general and special part. "ARSO", Sofia, 2002, 46-49. [in Bulgarian]

\section{Correspondence address:}

Assoc. prof. Hristina Lalabonova,

Department of Maxillofacial Surgery, Faculty of Dental Medicine,

11, Opalchenska Str., 4000 Plovdiv, Bulgaria

tel.: $+359 / 888608406$

e-mail: lalabonova@abv.bg; 